\title{
Effects of Lysine Levels of Diets Formulated Based on Total or Digestible Amino Acids on Broiler Carcass Composition
}

\section{author(s)}

Nasr J1

Kheiri $F^{2}$

Department of Animal Science, Faculty of Agriculture, Saveh Branch, Islamic Azad University, Saveh, Iran.

${ }^{2}$ Department of Animal Sceince, Shahrekord Branch, Islamic Azad University,

Shahrekord, Iran

\section{-Mail Adress}

Postal Code:39187/366 Mobile: 09121613290

Email: javadnasr@iau-saveh.ac.ir

Email : F.Kheiri@gmail.com

\section{EKeywords}

Amino acids, carcass, digestible, lysine, requirements.

\begin{abstract}
The study was conducted to evaluate carcass yield and chemical composition of thigh and breast muscles of broilers fed three different lysine requirement levels: high lysine (+10\% NRC), standard (NRC) and low lysine (-10\% NRC) and two ways of expressing amino acids in feedstuffs (total or digestible amino acids). The results of this study showed that diet formulation based on digestible amino acids significantly influenced breast yield and abdominal fat deposition. The study showed that increasing lysine level $(+10 \%$ NRC) of diet significantly increased both carcass and breast percentage and also carcass, breast and thigh weight. The interaction between digestible amino acids and lysine requirement levels affected carcass and breast percentage. Feeding broilers high lysine diets $(+10 \%$ NRC) significantly increased lysine content in breast and thigh. The response to formulation based on digestible amino acids was maximized when broilers received the high lysine level diet.
\end{abstract}

\section{INTRODUCTION}

Amino acids (AA) requirements of broilers have been extensively studied, as well as factors that influence such requirements, such as sex, age, genetic strain, heat stress, dietary energy concentration and its interaction with crude protein level (Acer et al. 1991, Baker \& Han 1994, Vazquez \& Pesti 1997, Garcia et al. 2006, Sterling et al. 2006). The wide variation in the composition and digestibility of AA present in feedstuffs is of great concern in diet formulation. The importance of feeding the correct amount of balanced dietary protein and AA for poultry is a priority for two reasons. First, protein and AA are some of the most expensive nutrients in feeds per weight unit. Second, there are environmental concerns as to nitrogen excretion in poultry waste.

The concentration of protein and AA in broiler diets has a large impact on breast meat yield, feed to gain ratio, and number of days required to achieve the appropriate body weight for each type of market. Depending upon genetic strain and market objectives of each broiler complex, a broiler integrator will probably utilize several different protein and AA dietary programs (Acer et al., 1991). In commercial practice, formulating diets to supply adequate AA minimum levels is critical to optimize live production and meat yield of broiler chickens. During the last 10 years, the demand for breast fillets and value-added products has led to increasing broiler market weights. Market weight, product mix, live cost, and genetic strain may determine AA supplementation. Amino acids are critical for muscle development (Tessseraud et al., 1996) and lysine (Lys) content in the breast muscle is relatively higher than other AA (Munks et al., 1945). Lysine represents approximately $7 \%$ of the protein in breast meat (Munks et al., 1945). Dietary Lys inadequacy 
has been shown to reduce breast meat yield compared with other muscles (Tessseraud et al., 1996). Therefore, defining dietary AA needs for optimal growth and meat yield is of utmost importance.

Lysine, one the key AA for protein synthesis and muscle deposition has also been demonstrated to be involved in the synthesis of cytokines, proliferation of lymphocytes and thus in the optimal functioning of immune system in response to infection. Inadequate Lys supply reduces antibody response and cell-mediated immunity in chickens (Geraert \& Mercier, 2010).

Lysine needed for optimizing breast meat yield may be higher than the amount needed for optimal body weight gain and feed efficiency (Moran \& Bilgili, 1990, Acar et al., 1991, Gorman \& Balnave, 1995). Holsheimer \& Ruesink (1998) showed that breast meat yield was increased in male broilers fed a diet containing increasing Lys levels from 1-14 days of age; however, their performance was not affected by dietary Lys from 15 to 49 days of age. It Is well known that protein and Lys and their interaction are important factors that affect performance and carcass quality of growing chickens and therefore, dietary protein requirement is actually the requirement of Lys contained in the protein.

The objective of the nutritionists has long been to optimize growth and tissue accretion by increasing nutrient density such as $A A$. The question remains about the potential benefits of AA beyond protein synthesis for muscle development. The overall efficiency of lysine used for protein accretion in young growing chicks and pigs is between 70 and $80 \%$ (Edwards et al., 1999; Mohn et al., 2000). Essential amino acid recommendations for broilers in the NRC (1994) are largely based on experimentation conducted several decades ago.

Therefore the objective of this study was to evaluate the effects of three different lysine requirement levels -high lysine (+10\% NRC), standard (NRC) and low lysine $(-10 \% \mathrm{NRC})$ - and two ways of expressing amino acid levels in feedstuffs - total amino acids (TAA) or digestible amino acids (DAA) - on the yield and chemical composition of thigh and breast meat of Arian broilers.

\section{MATERIAL AND METHODS}

An experiment with Arian male broilers was conducted from 1 to 6 weeks of age. On day 1, 300 male chicks were placed in 30 floor pens (10 chicks per pen and $0.1 \mathrm{~m}^{2}$ floor space/chick). Water and feed were supplied ad libitum. A continuous lighting regimen was adopted, with 24 hours of light daily, throughout the experimental periods.

The basic chemical composition of the feedstuffs and of breast and thigh muscles was determined according to AOAC (1990).

The total amino acid values of the ingredients were assayed by high-pressure liquid chromatography analysis (Moore, 2004). In order to determine digestibility, TAA levels determined in the analysis were multiplied by their respective digestibility coefficients, as determined by Yaghobfar $(2002,2003)$.

A completely randomized experimental design in a factorial scheme $(2 \times 3)$ was applied. The first factor included three different lysine requirement levels - high lysine (+10\% NRC), standard (NRC) and low lysine $(-10 \% \mathrm{NRC})$ - and the second factor included formulation based on total amino acid (TAA) or digestible amino acid (DAA) levels. Therefore, the following treatments were applied:

1. Diet with high lysine (H Lys) requirement level (+\%10 NRC), formulation based on TAA,

2. Diet with standard lysine (S Lys) requirement level (NRC), formulation based on TAA,

3. Diet with low lysine ( $L$ Lys) requirement level ($\% 10 \mathrm{NRC}$ ), formulation based on TAA,

4. Diet with high lysine (H Lys) requirement level (+\%10 NRC), formulation based on DAA,

5. Diet with standard lysine (S Lys) requirement level (NRC), formulation based on DAA,

6. Diet with low lysine (L Lys) requirement level ($\% 10$ NRC), formulation based on DAA.

Feeds were provided in mash form and were milled with a 3-mm screen to obtain a similar particle size in all diets. Diets wereformulated, according to NRC (1994) recommendations, to contain $23 \% \mathrm{CP}$ and $3,100 \mathrm{kcal}$ of $\mathrm{ME} / \mathrm{kg}$ in starter period and 19\% CP and 3,200 $\mathrm{kcal} \mathrm{ME} / \mathrm{kg}$ in grower period. Diets were formulated to contain equal energy and nitrogen levels and were based on corn and soybean meal (ileal digestibility coefficients of 0.81-0.81), in which AA are highly digestible (Ravindran et al., 2005). Diet composition is shown in Tables 1 and 2.

At the end of the experimental period (42 days of age), in order to evaluate carcass quality, three birds per replicate, with body weights as close as possible to the average body weight of the experimental unit, were slaughtered. Birds were weighed, de-feathered, eviscerated, and weighed again to obtain carcass weight (without head and feet), and breast, thigh, liver and abdominal fat weights. Breast, thigh and carcass 
yields were determined as carcass weight relative to body weight and expressed as a percentage of body weight (\%).

Parameters were tested for normal distributions before analyses. Data were analyzed per factor (GLM procedure, ANOVA, SAS Institute, 2001) and where significance was detected, means were compared by Duncan's multiple range tests. Output data are expressed as means and SEM.

\section{RESULTS AND DISCUSSION}

The main effects of diet formulation based on DAA or TAA did not influence carcass, thigh percentage and liver weight (Table 3). These results are consistent with those of Rostagno et al. (1995) and Dari \& Penz (1996), who found no differences in carcass yield. Diets formulated on DAA, however, significantly influenced breast percentage and abdominal fat deposition (Table 3). Breast percentage and abdominal fat were

Table 1 - Composition of experimental diets in starter $(0-21 \mathrm{~d})$ period.

\begin{tabular}{|c|c|c|c|c|c|c|c|}
\hline \multirow{2}{*}{$\begin{array}{l}\text { Diet formulation based on } \\
\text { Lysine requirement levels }\end{array}$} & & \multicolumn{3}{|c|}{ Total AA } & \multicolumn{3}{|c|}{ Digestible AA } \\
\hline & & $+10 \%$ & Standard & $-10 \%$ & $+10 \%$ & Standard & $-10 \%$ \\
\hline+ & Treatment & 1 & 2 & 3 & 4 & 5 & 6 \\
\hline Corn, Grain & & 55.47 & 56.27 & 57.32 & 54.01 & 55.01 & 55.39 \\
\hline Soybean Meal -48\% & & 35.56 & 35.01 & 33.94 & 37 & 36.21 & 36.01 \\
\hline Soybean Oil & & 3 & 3 & 3 & 2.8 & 2.8 & 2.8 \\
\hline Fish Meal & & 2 & 2 & 2 & 2 & 2 & 2 \\
\hline Oyster Shells & & 1.88 & 1.88 & 1.88 & 1.88 & 1.88 & 1.88 \\
\hline Dicalcium phosphate & & 1 & 1 & 1 & 1 & 1 & 1 \\
\hline Common Salt & & 0.2 & 0.2 & 0.2 & 0.2 & 0.2 & 0.2 \\
\hline Vitamin Premix * & & 0.25 & 0.25 & 0.25 & 0.25 & 0.25 & 0.25 \\
\hline Mineral Premix * & & 0.25 & 0.25 & 0.25 & 0.25 & 0.25 & 0.25 \\
\hline DL-Methionine & & 0.11 & 0.09 & 0.1 & 0.11 & 0.1 & 0.1 \\
\hline L-Lysine $\mathrm{HCl}$ & & 0.28 & 0.05 & 0.05 & 0.5 & 0.3 & 0.12 \\
\hline \multicolumn{8}{|l|}{ Nutritional composition } \\
\hline Metabolizable Energy (Mcal/Kg) & & 3.10 & 3.10 & 3.10 & 3.10 & 3.10 & 3.10 \\
\hline Protein (\%) & & 23.00 & 23.00 & 23.00 & 23.00 & 23.00 & 23.00 \\
\hline Ether Extract (\%) & & 5 & 5 & 5 & 5 & 5 & 5 \\
\hline Linoleic Acid (\%) & & 2.5 & 2.5 & 2.5 & 2.5 & 2.5 & 2.5 \\
\hline Calcium (\%) & & 1.00 & 1.00 & 1.00 & 1.00 & 1.00 & 1.00 \\
\hline Avail. Phosphorus (\%) & & 0.5 & 0.5 & 0.5 & 0.5 & 0.5 & 0.5 \\
\hline Sodium (\%) & & 0.16 & 0.16 & 0.16 & 0.16 & 0.16 & 0.16 \\
\hline LYS (\%) & & 1.25 & 1.14 & 1.03 & 1.25 & 1.14 & 1.03 \\
\hline MET (\%) & & 0.51 & 0.51 & 0.51 & 0.51 & 0.51 & 0.51 \\
\hline TSAA (\%) & & 1.11 & 1.11 & 1.11 & 1.11 & 1.11 & 1.11 \\
\hline
\end{tabular}

*Supplied per kg of diet: vitamin A (7,000 IU), vitamin D3 (1,400 IU), vitamin E (16.65 mg), vitamin K (1.5 mg), vitamin B1 (0.6 mg), vitamin B2 (2.36 $\mathrm{mg}$ ), vitamin B6 $(0.6 \mathrm{mg})$, vitamin B12 $(0.013 \mathrm{mg})$, biotin $(0.15 \mathrm{mg})$, choline (1.54 g), pantothenic acid $(9.32 \mathrm{mg})$, niacin (30.12 mg), folic acid (1.42 $\mathrm{mg}$ ), selenium (0.65 mg), iodine (0.35 mg), iron (57.72 mg), copper (12.30 mg), zinc (141.48 mg), manganese (173 mg). 
Table 2 - Composition of experimental diets in grower (22-42 d) period.

\begin{tabular}{|c|c|c|c|c|c|c|c|}
\hline \multirow{2}{*}{$\begin{array}{l}\text { Diet formulation based on } \\
\text { Lysine requirement levels }\end{array}$} & & \multicolumn{3}{|c|}{ Total AA } & \multicolumn{3}{|c|}{ Digestible AA } \\
\hline & & $+10 \%$ & Standard & $-10 \%$ & $+10 \%$ & Standard & $-10 \%$ \\
\hline Item & Treatment & 1 & 2 & 3 & 4 & 5 & 6 \\
\hline Corn, Grain & & 65.6 & 65.9 & 66.78 & 64.97 & 65.87 & 67.6 \\
\hline Soybean Meal -48\% & & 28.72 & 28.2 & 27.14 & 28.93 & 28.1 & 27.01 \\
\hline Soybean Oil & & 3 & 3.24 & 3.22 & 3.27 & 3.4 & 3 \\
\hline Oyster Shells & & 1.6 & 1.7 & 1.8 & 1.5 & 1.5 & 1.4 \\
\hline Dicalcium phosphate & & 0.2 & 0.2 & 0.2 & 0.23 & 0.23 & 0.23 \\
\hline Common Salt & & 0.2 & 0.2 & 0.2 & 0.2 & 0.2 & 0.2 \\
\hline Vitamin Premix * & & 0.25 & 0.25 & 0.25 & 0.25 & 0.25 & 0.25 \\
\hline Mineral Premix * & & 0.25 & 0.25 & 0.25 & 0.25 & 0.25 & 0.25 \\
\hline DL-Methionine & & 0.1 & 0.06 & 0.11 & 0.2 & 0.1 & 0.06 \\
\hline L-Lysine $\mathrm{HCl}$ & & 0.08 & 0 & 0.05 & 0.2 & 0.1 & 0 \\
\hline \multicolumn{8}{|l|}{ Nutritional composition } \\
\hline Metabolizable Energy (Mcal/kg) & & 3.2 & 3.2 & 3.2 & 3.2 & 3.2 & 3.2 \\
\hline Protein (\%) & & 19 & 19 & 19 & 19 & 19 & 19 \\
\hline Ether Extract (\%) & & 5 & 5 & 5 & 5 & 5 & 5 \\
\hline Linoleic Acid (\%) & & 2.5 & 3 & 2.5 & 2.5 & 3 & 2.5 \\
\hline Calcium (\%) & & 0.09 & 0.09 & 0.09 & 0.09 & 0.09 & 0.09 \\
\hline Avail. Phosphorus (\%) & & 0.42 & 0.42 & 0.42 & 0.42 & 0.42 & 0.42 \\
\hline Sodium (\%) & & 0.16 & 0.16 & 0.16 & 0.16 & 0.16 & 0.16 \\
\hline LYS (\%) & & 1.1 & 1 & 0.9 & 1.1 & 1 & 0.9 \\
\hline $\operatorname{MET}(\%)$ & & 0.42 & 0.42 & 0.42 & 0.42 & 0.42 & 0.42 \\
\hline TSAA (\%) & & 0.88 & 0.88 & 0.88 & 0.88 & 0.88 & 0.88 \\
\hline
\end{tabular}

*supplied per kg of diet: vitamin A (7,000 IU), vitamin D3 (1,400 IU), vitamin E (16.65 mg), vitamin $\mathrm{K}(1.5 \mathrm{mg})$, vitamin B1 (0.6 mg), vitamin B2 (2.36 $\mathrm{mg}$ ), vitamin B6 $(0.6 \mathrm{mg})$, vitamin B12 $(0.013 \mathrm{mg})$, biotin $(0.15 \mathrm{mg})$, choline $(1.54 \mathrm{~g})$, pantothenic acid $(9.32 \mathrm{mg})$, niacin (30.12 mg), folic acid (1.42 $\mathrm{mg})$, selenium $(0.65 \mathrm{mg})$, iodine $(0.35 \mathrm{mg})$, iron $(57.72 \mathrm{mg})$, copper $(12.30 \mathrm{mg})$, zinc $(141.48 \mathrm{mg})$, manganese $(173 \mathrm{mg})$.

significantly higher when the diet was formulated on DAA basis $(p<0.05)$. This may explained by a close relationship between abdominal fat weight and dietary energy:protein ratio. Excessive AA intake is related to the energy: protein ratio in the diet, and consequently, to carcass composition. In the present study, diets were formulated to contain equal amino acid (isonitrogenous) and energy (iso-energetic) levels, but based either on different formulation criteria (total or digestible amino acids) and different lysine requirement levels. Therefore, the AA intake of broilers fed the diets formulated based on DAA was higher than of those fed the TAA-based diet. When crude protein intake increases, the energy: protein ratio is reduced, resulting in fatter carcasses (Summers et al., 1965, Griffiths et al., 1977, Rosebrough \& Steele, 1985). Postnatal protein accretion results from an increase in protein synthesis or a decrease in protein degradation. Diets containing low Lys may limit breast meat development early in development as protein synthesis and RNA content are reduced (Tesseraud et al., 1992, 1996). 
Table 3 - Effects of amino acids of feedstuffs and lysine requirement levels on carcass composition.

\begin{tabular}{|c|c|c|c|c|c|c|}
\hline $\mathrm{T}$ & (AA formulation $\times$ Lys levels) & $\begin{array}{l}\text { Carcass } \\
(\%)\end{array}$ & $\begin{array}{l}\text { Breast } \\
(\%)\end{array}$ & $\begin{array}{l}\text { Thigh } \\
(\%)\end{array}$ & $\begin{array}{l}\text { Abdominal } \\
\text { Fat }(\mathrm{g})\end{array}$ & $\begin{array}{l}\text { Liver } \\
\text { (g) }\end{array}$ \\
\hline 1 & $($ TAA $x+10 \%$ NRC $)$ & $66.63 a$ & $21.59 a$ & 22.62 & $17.05 b$ & $53.85 \mathrm{ab}$ \\
\hline 2 & $($ TAA $\times$ Standard NRC) & $66.18 \mathrm{a}$ & $21.19 a$ & 22.79 & $15.10 \mathrm{~b}$ & $53.63 \mathrm{ab}$ \\
\hline 3 & $($ TAA $\times-10 \%$ NRC) & $60.94 \mathrm{~b}$ & $18.88 b$ & 21.88 & $19.10 \mathrm{~b}$ & $42.55 b$ \\
\hline 4 & $(\mathrm{DAA} \times+10 \% \mathrm{NRC})$ & $65.18 \mathrm{a}$ & $21.92 \mathrm{a}$ & 23.30 & 40.33 a & $60.40 \mathrm{a}$ \\
\hline 5 & $($ DAA $\times$ Standard NRC) & $66.35 a$ & $21.27 \mathrm{a}$ & 23.71 & $12.43 b$ & $49.35 \mathrm{ab}$ \\
\hline \multirow[t]{14}{*}{6} & $(\mathrm{DAA} \times-10 \% \mathrm{NRC})$ & $63.03 a b$ & $20.78 a b$ & 21.63 & $33.10 \mathrm{a}$ & $55.75 \mathrm{ab}$ \\
\hline & $p$-value & 0.017 & 0.087 & 0.332 & 0.002 & 0.146 \\
\hline & (SEM) & 1.175 & 0.381 & 0.719 & 4.577 & 4.422 \\
\hline & \multicolumn{6}{|l|}{ Amino Acids in Feedstuffs } \\
\hline & Total & 64.58 & $20.56 b$ & 22.43 & $17.08 \mathrm{~b}$ & 50.01 \\
\hline & Digestible & 64.85 & $21.79 a$ & 22.88 & 28.62 a & 55.17 \\
\hline & P-value & 0.780 & 0.042 & 0.452 & 0.006 & 0.170 \\
\hline & (SEM) & 0.678 & 0.293 & 0.415 & 2.643 & 2.553 \\
\hline & \multicolumn{6}{|l|}{ Lysine requirement levels } \\
\hline & $+10 \%$ NRC & $65.91 \mathrm{a}$ & $21.76 \mathrm{a}$ & 22.96 & $28.69 a$ & 57.13 \\
\hline & Standard & $66.26 \mathrm{a}$ & $21.24 a b$ & 23.25 & $13.76 b$ & 51.49 \\
\hline & $-10 \% N R C$ & $61.98 b$ & $19.83 b$ & 21.75 & $26.10 b$ & 49.15 \\
\hline & $\mathrm{p}$-value & 0.003 & 0.041 & 0.116 & 0.010 & 0.207 \\
\hline & (SEM) & 0.831 & 0.181 & 0.508 & 3.237 & 3.127 \\
\hline
\end{tabular}

${ }^{a-c}$ Means followed by different superscript are significantly different $(p<0.05)$.

Dietary lysine requirement levels had no influence on thigh percentage and liver weight. The results confirmed the findings of previous studies that demonstrated that Lys requirements for growing chickens are higher than the NRC's (1994) recommendation for maximal growth (Kidd et al.,1998; Kerr et al., 1999). It is also confirmed that increasing dietary Lys level increases breast meat yield (Kerr et al., 1999).

Dietary lysine levels significantly influenced carcass and breast percentage (Table 3), as well as carcass, breast and thigh weights (Figure 2). Abdominal fat weight significantly increased when Lys levels were above or below the requirements. This higher abdominal fat deposition is probably related to AA imbalance of these diets. This study showed that higher dietary Lys level (+10\% NRC) significantlyincreased breast meat yield, as shown in other research studies (Bilgili et al.,1992; Gorman \& Balnave, 1995; Han \& Baker, 1994; Kidd et al., 1998). Although feeding high Lys diets throughout the rearing period optimizes breast meat yield (Kidd et al., 1998; Kerr et al., 1999), it may not always be economically justified. However, evidence in literature suggests that feeding high Lys diets during the starter period impacts subsequent breast meat yield at marketing (Holsheimer \& Ruesink, 1993; Kerr et al., 1999). Dietary Lys concentration can significantly influence breast meat yield because the breast has high Lys content (Table 4) and it represents a large portion of carcass meat. Breast muscle development is also affected by sex, age, breed and genetics strain (Moran \& Bilgili, 1990; Acar et al., 1991; Bilgili et al., 1992, Gorman \& Balnave, 1995; Han \& Baker, 1991), and these studies also showed that an additional dietary Lys increases breast meat accretion.

Treatment 4 (H Lys $\times$ DAA) promoted significantly higher carcass, breast and thigh weights than the 
Table 4 - Effects of amino acids of feedstuffs and lysine requirement levels on chimical composition

\begin{tabular}{|c|c|c|c|c|c|c|c|}
\hline \multirow{2}{*}{$\mathrm{T}$} & \multirow{2}{*}{ (AA formulation $\times$ Lys levels) } & \multicolumn{3}{|c|}{ Breast Meat } & \multicolumn{3}{|c|}{ Thigh Meat } \\
\hline & & Lys (\%) & $\mathrm{Li}(\%)$ & $\mathrm{CP}(\%)$ & Lys (\%) & $\mathrm{Li}(\%)$ & $\mathrm{CP}(\%)$ \\
\hline 1 & $($ TAA $x+10 \%$ NRC $)$ & $5.83 \mathrm{a}$ & 5.53 & 57.91 & $5.05 \mathrm{a}$ & 9.86 & 60.59 \\
\hline 2 & $($ TAA $\times$ Standard NRC) & $4.43 b$ & 3.04 & 49.26 & $3.83 b$ & 9.60 & 52.22 \\
\hline 3 & $($ TAA $\times-10 \%$ NRC) & $3.92 b$ & 6.49 & 45.64 & $3.05 b$ & 11.39 & 48.74 \\
\hline 4 & $(\mathrm{DAA} \times+10 \% \mathrm{NRC})$ & 5.89 a & 4.77 & 59.34 & $5.40 \mathrm{a}$ & 9.30 & 64.66 \\
\hline 5 & $($ DAA $\times$ Standard NRC) & $4.29 \mathrm{~b}$ & 3.66 & 52.17 & $3.92 \mathrm{~b}$ & 9.06 & 53.11 \\
\hline \multirow[t]{14}{*}{6} & $($ DAA $\times-10 \% N R C)$ & $4.09 \mathrm{~b}$ & 3.76 & 45.10 & $3.55 \mathrm{a}$ & 11.59 & 49.82 \\
\hline & p-value & 0.009 & 0.295 & 0.289 & 0.002 & 0.517 & 0.122 \\
\hline & (SEM) & 0.424 & 1.128 & 5.211 & 0.362 & 1.162 & 4.452 \\
\hline & \multicolumn{7}{|l|}{ Amino Acids in Feedstuffs } \\
\hline & Total & 4.73 & 5.021 & 50.94 & 3.98 & 10.28 & 53.85 \\
\hline & Digestible & 4.76 & 4.061 & 52.20 & 4.29 & 9.980 & 55.86 \\
\hline & p-value & 0.93 & 0.311 & 0.769 & 0.30 & 0.755 & 0.587 \\
\hline & (SEM) & 0.245 & 0.651 & 3.009 & 0.209 & 0.671 & 2.569 \\
\hline & \multicolumn{7}{|l|}{ Lysine requirement levels } \\
\hline & $+10 \% \mathrm{NRC}$ & $5.86 a$ & 5.149 & 58.63 & $5.23 \mathrm{a}$ & 9.579 & $62.63 a$ \\
\hline & Standard & $4.36 b$ & 3.35 & 50.72 & $3.88 a b$ & 9.33 & $52.67 b$ \\
\hline & $-10 \% N R C$ & $4.00 \mathrm{~b}$ & 5.13 & 45.37 & $3.30 \mathrm{~b}$ & 11.49 & $49.28 \mathrm{~b}$ \\
\hline & p-value & 0.001 & 0.215 & 0.061 & 0.000 & 0.155 & 0.021 \\
\hline & (SEM) & 0.299 & 0.798 & 3.685 & 0.256 & 0.822 & 3.148 \\
\hline
\end{tabular}

${ }^{a-c}$ Means followed by different superscript are significantly different $(p<0.05)$.

other treatments (Figure1). This study showed the higher efficiency of these diets as they allow a better utilization of dietary AA for tissue synthesis and accretion. This is possibly related to a higher AA availability to synthesize muscle. Diets formulated with high Lys levels promoted a better conversion of DAA into carcass and breast yield. It was also verified that the $\mathrm{H}$ Lys diet formulated on DAA basis promoted better conversion of AA into carcass and breast percentage (Table 3) and carcass, breast and thigh weight (Figure 1) compared with other treatments. The combination of DAA and standard Lys level possibly resulted in less AA available for fat deposition.

Genetic differences have been observed for breast meat yield, abdominal fat pad percentage, and yields of other parts (Acar et al., 1991; Holsheimer \& Veerkamp, 1992; Smith \& Pesti, 1998; Smith et al., 1998). Leclercq (1998) stated that the required level of lysine is highest for minimizing abdominal fat pad percentage followed by maximizing breast meat yield and body weight gain. Acar et al. (1991) found significant interactions of genotype with lysine for abdominal fat, breast fillet, and breast tender yields. However, dietary protein level has been found to affect the lysine requirement (expressed as a percentage of the diet) of chicks (Morris et al., 1987; Hurwitz et al., 1998; Sterling et al., 2002). Feeding high-Lys and AA-dense diets to broilers increases breast meat yield (Dozier et al., 2007; Eits et al., 2003). Dietary AA responses influencing breast meat yield may be additive among AA (De Leon, 2006; Hickling et al., 1990; Kerr et al., 1999), but other studies found no interactions between Lys and Met (Si et al., 2004). Differences in dietary AA density responses in literature (Corzo et al., 2004 and 2005; Kidd et al., 2004) may be related to genetic lines. The response to dietary AA/CP density 

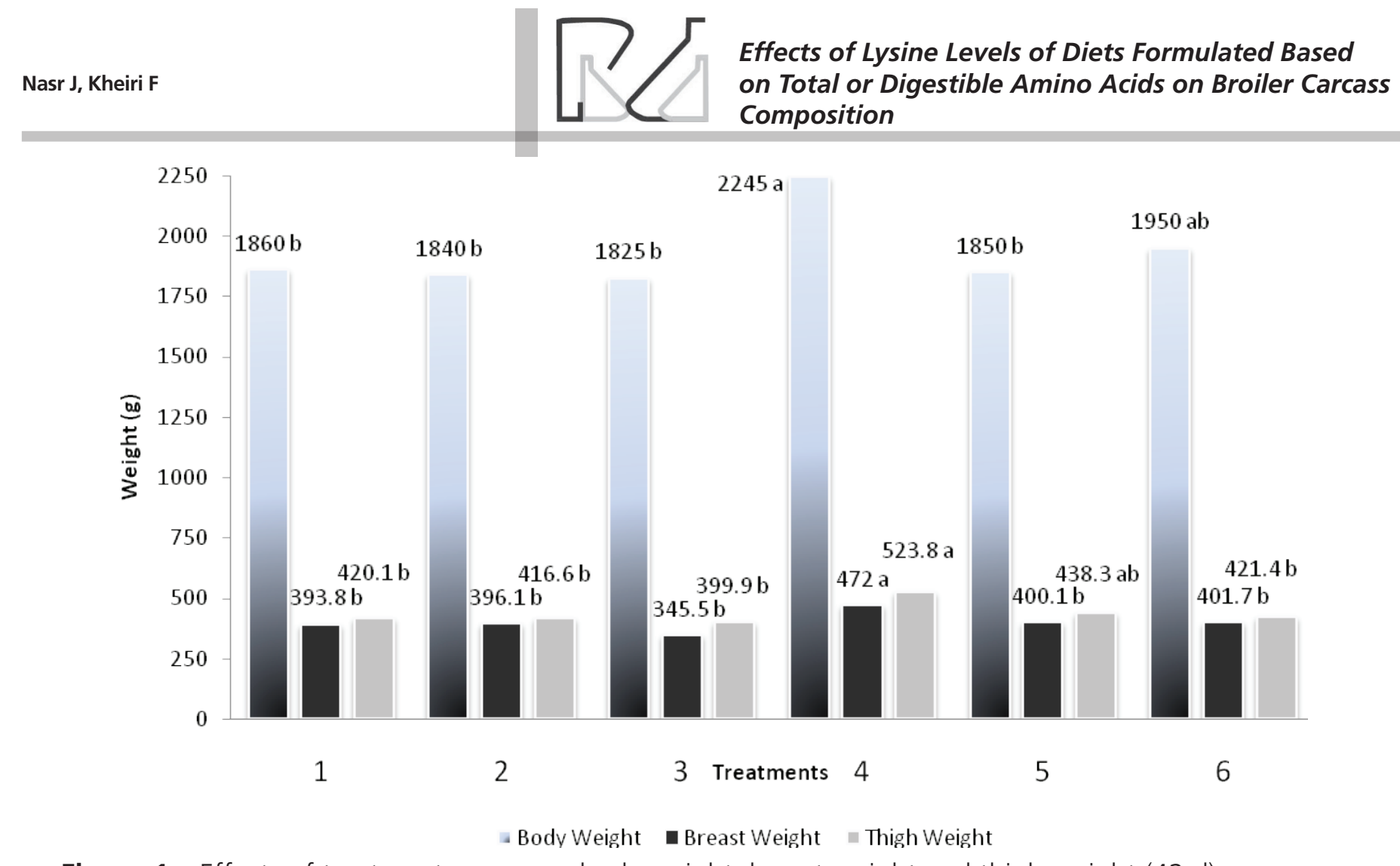

Figure 1 - Effects of treatments on mean body weight, breast weight and thigh weight (42 d).

Treatment 1: diet with + \%10 NRC (1994) lysine requirement level, formulation based on TAA, Treatment 2: diet with standard NRC (1994) lysine requirement level, formulation based on TAA, Treatment 3: diet with - \%10 NRC (1994) lysine requirement level, formulation based on TAA, Treatment 4: diet with + \%10 NRC (1994) lysine requirement level, formulation based on DAA, Treatment 5: diet with standard NRC (1994) lysine requirement level, formulation based on DAA, Treatment 6: diet with - \%10 NRC (1994) lysine requirement level, formulation based on DAA. a-c Means followed by different superscript are significantly different $(p, 0.05)$.

(Smith \& Pesti, 1998; Smith et al., 1998; Sterling et al., 2006) and dietary Lys (Bilgili et al., 1992; Acar et al., 1991; Han \& Baker, 1991; Pesti et al., 1994) differs among genetic lines. A high-yielding strain was shown to contain more breast muscle total RNA and protein on a weight basis and total DNA content than a lowyielding strain (Acar et al., 1993). Muscle growth is largely related to the number of nuclei or total DNA (Kang et al., 1985). Hence, strains exhibiting rapid muscle growth should have balanced high dietary AA requirements for muscle accretion. In some previous studies, feeding low protein diets to broilers impaired growth performance (Ferguson et al., 1998; Jacob et al., 1994; Jensen, 1991). It has been suggested that amino acid requirements of broilers linearly increase with dietary CP (Garu, 1984; Boomgaardt \& Baker, 1973; Morris et al., 1987; Morris \& Abbeb, 1990; Morris et al., 1992).

Although in the present study treatment 4 (H Lys $x$ DAA) promoted the highest carcass, breast and thigh weights (Figure 1), poor-quality dietary proteins and AA may cause major problems in broiler production. The reason dietary protein and AA cause high heat increment from metabolism is the inefficient process of incorporating feed protein and AA into body proteins. The formation of new body proteins both from endogenous and dietary AA can be inefficient with regard to using available metabolic energy. The nitrogen that is not utilized by the body need be converted into a non-toxic metabolite called uric acid and eliminated from the body. The production of the nitrogen waste product, uric acid, requires a significant amount of metabolic energy, which is taken away from the energy needed for growth. This was shown in the present study, where the diet fomulated based on DAA and with high $\mathrm{H}$ Lys resulted in significantly higher carcass and breast yield, whereas the broilers fed the diet fomulated on TAA basis and low Lys level presented the lowest carcass and breast yield.

Main effects of diet formulation based on DAA or TAA and lysine requirements levels did not affect breast and thigh meat protein or lipid contents. The breast contains a higher percentage of lysine and methionine than other body components (6.5 and $1.96 \%$, respectively) and the thigh contains a 5.86 and $1.93 \%$ of lysine and methionine, respectively, in Ross broilers (Coon, 2000). The overall increase in carcass lysine and methionine in amino acid composition 


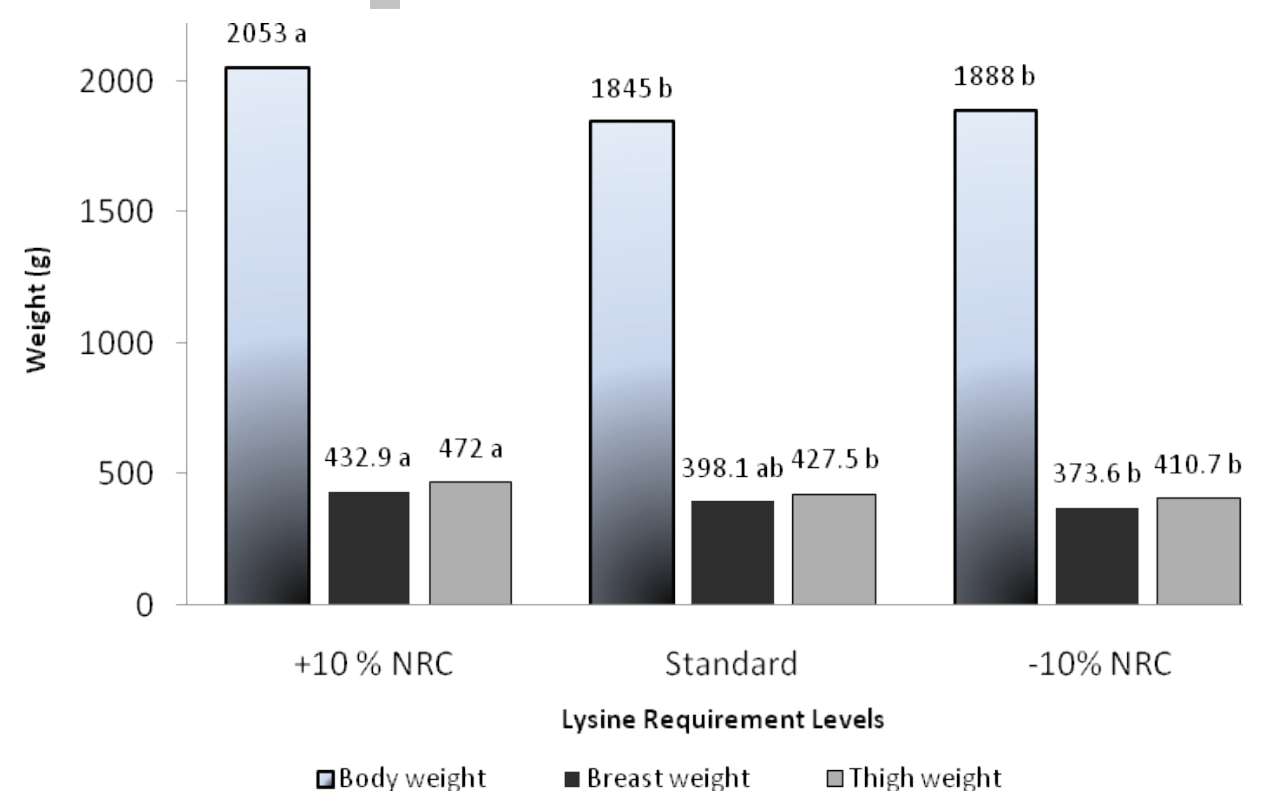

Figure 2 - Effects of lysine requirement levels on mean body, breast and thigh weights (42 d).

${ }^{a-c}$ Means followed by different superscript are significantly different $(p, 0.05)$.

in older broilers because breast meat percentage increases in older broilers is probably the reason why these AA have been shown to increase breast meat yield (Table 3, 4). The amino acid requirements for different genetic broiler lines are partially dependent on the amino acid content of each body component (i.e., breast, thigh, drumstick) and on the extent to which the carcass components change as a percentage of the whole bird. In present study, however, breast and thigh lysine percentages were 4.742 and 4.133 , respectively, which were lower than in Ross broilers. Lysine represents approximately $7 \%$ of the protein in breast meat (Munks et al., 1945).

Amino acids effects beyond their roles of building blocks of the protein accretion have been largely demonstrated, from a better gut functioning to an enhanced immune system. More research is necessary to determine the optimal AA requirements to improve not only muscle development, but also meat quality. It has been determined that optimal AA levels are not the same for maximization weight gain and breast muscle development (Pesti \& Miller, 1997), but in the present study, the high dietary Lys level promoted the highest body, breast and thigh weights (Figure 2).

\section{CONCLUSION}

Feeding broilers high lysine diets ( $+10 \% \quad$ NRC) increases carcass and breast percentages by $4.4 \%$ and $1.81 \%$, respectively, compared with broilers fed low lysine diets. Diet formulation based on digestible amino acids levels in feedstuffs and high lysine dietary levels influence broiler carcass and breast percentage. The interaction between digestible amino acids and high lysine level allows the full expression of the genetic potential for growth of Arian broilers. Formulating broiler diets based on digestible amino acids provides better prediction of dietary protein quality and bird performance than total amino acids. Feeding broilers high lysine density diets (+10\% NRC) significantly increase percentage of lysine in breast and thigh meat.

\section{REFERENCES}

Acar N, Moran Jr ET, Bilgili SF. Live performance and carcass yield of male broilers from two commercial strain crosses receiving rations containing lysine below and above the established requirement between six and eight weeks of age. Poultry Science 1991;70:2315-2321.

Acar N, Moran Jr ET, Mulvaney DR. Breast muscle development of commercial broilers from hatching to twelve weeks of age. Poultry Science 1993;72:317-325.

Association of Official Analytical Chemist. Official methods of analysis Association of Official Analytical Chemists. 15 th ed. Gaithersburg; 1990.

Baker DH, Han Y. Ideal amino acid profile for chickens during the first three weeks of growth. Poultry Science 1994:73:1441-1447.

Bilgili SF, Moran JrET, Acar N. Strain-cross response of heavy male broilers to dietary lysine in the finisher feed: Live performance and further processing yields. Poultry Science 1992;71:850-858.

Boomgaardt JO, Baker $\mathrm{DH}$. The lysine requirement of growing chicks fed sesame mealgelatin diet at three protein level. Poultry Science 1973;52:586-591. 
Coon C. The Ideal Amino Acid Requirements and Profile for Broilers Layers and Broiler Breeders. Saint Louis: American Soybean Association; 2000.

Corzo A, McDaniel CD, Kidd MT, Miller ER, Boren B, Fancher BI. Impact of dietary amino acid concentration on growth carcass yield and uniformity of broilers. Australian Journal of Agricultural Research 2004;55:1133-1138.

Corzo A, Kidd MT, Dozier WA, Walsh TJ, Peak SD. Impact of dietary amino acid density on broilers grown for the small bird market. Japan Poultry Science 2005:42:329-336.

Dari RL, Penz JrAM. The use of digestible amino acid and ideal protein concept in diet formulation for broilers. Poultry Science 1996; 75:Suppl 67.

De Leon AC. Limiting dietary amino acids and metabolizable energy response surface estimates for growing broilers [thesis]. Mississippi (MS): State University Mississippi State; 2006.

Dozier WA, Corzo A, Kidd MT, Branton SL. Dietary apparent metabolizable energy and amino acid density effects on growth and carcass traits of heavy broilers. The Journal Applied Poultry Research 2007;16:192-205.

Edwards HM, Fernandez SR, Baker DH. Maintenance lysine requirement and efficiency of using lysine for accretion of whole-body lysine and protein in young chicks. Poultry Science 1999; 78:1412-7.

Eits RM, Kwakkel RP, Verstegen MW, Emmans GC. Responses of broiler chickens to dietary protein: Effects of early life protein nutrition on later responses. British Poultry Science 2003; 44:398-409.

Ferguson NS, Gates RS, Taraba Jl, Cantor AH, Pescatore AJ, Ford MJ, Burnham DJ. The effect of dietary crude protein on growth ammonia concentration and litter composition in broiler. Poultry Science 1998;71:1481-1487

Garcia AR, Batal AB, Baker DH. Variations in the digestible lysine requirement of broiler chickens due to sex performance parameters rearing environment and processing yield characteristics. Poultry Science 2006;85:498-504

Garu CR. Effect of protein level on the lysine requirement of the chicks. Journal of Nutrition 1984;36:99-108.

Geraert PA, Mercier Y. Amino acids: beyond the building blocks! Antony: ADISSEO France SAS; 2010.

Gorman I, Balnave D. The effect of dietary lysine and Methionine on the growth characteristics and breast meat yield of Australian broiler chickens. Australian Jounal of Agricultural Research . 1995; 46:15691577.

Griffiths L, Lesson S, Summers JD. Fat deposition in broilers: Effect of dietary energy to protein balance and early life caloric restriction on productive performance and abdominal fat pad size. Poultry Science 1977; 56:638-646.

Han Y, Baker DH. Lysine requirements of fast- and slow-growing broiler chicks. Poultry Science 1991;70:2108-2114.

Hickling D, Guenter W, Jackson ME. The effects of dietary methionine and lysine on broiler chicken performance and breast meat yield. Canadian Journal of Animal Science 1990;70:673-678.

Holsheimer JP, Ruesink EW. Effect on performance carcass composition yield and financial return of dietary energy and lysine levels in starter and finisher diets fed to broilers. Poultry Science 1993; 72:806-815.

Holsheimer JP, Ruesink EW. Effect of performance carcass composition yield and financial return of dietary energy and lysine levels in starter and finisher diet fed to broiler. Poultry Science 1998; 77:806-815.
Holsheimer JP, Veerkamp CH. Effect of dietary energy protein and lysine content on performance and yields of two strains of male broiler chicks. Poultry Science 1992;71:872-879.

Hurwitz S, Sklan D, Talpaz H, Plavnik I. The effect of dietary protein level on the lysine and arginine requirements of growing chickens. Poultry Science 1998;77:689-696.

Jackson MR, Li S, Day EJ, Omar S. The effect of different lysine level fed in constant proportion to different crude protein level on the live performance and carcass characteristics of broiler chicken [abstract]. Poultry Science 1989;68 Suppl 186

Jacob JP, Blair R, Bennett DC, Scott TR, Newberry RC. The effect of dietary protein and amino acid levels during the grower phase on nitrogen excretion of broiler chicken. Proceedings of Canadian Animal Science Meeting; 1994; Saskatoon, Saskatchewan. Canada.

Kang CW, Sunde ML, Swick RW. Characteristics of growth and protein turnover in skeletal muscle of turkey poults. Poultry Science 1985:64:380-387.

Kerr BJ, Kidd MT, McWard GW, Quarles CL. Interactive effects of lysine and threonine on live performance and breast yield in male broilers. The Journal of Applied Poultry Research 1999; 8:391-399.

Kerr BJ, Kidd MT, Halpin KM, McWard GW, Quarles CL. Lysine level increases live performance and breast yield in male broilers and breast yield in male broilers. The Journal of Applied Poultry Research 1999;8:381390.

Kidd MT, Kerr BJ, Halpin KM, McWard GW, Quarles CL. Lysine levels in starter and grower- finisher diets affect broiler performance and carcass traits. The Journal of Applied Poultry Research 1998; 7:351-358.

Kidd MT, McDaniel CD, Branton SL, Miller ER, Boren BB, Fancher BI. Increasing amino acid density improves live performance and carcass yields of commercial broilers. The Journal of Applied Poultry Research 2004;13:593-604.

Leclercq B. Specific effects of lysine on broiler production: Comparison with threonine and valine. Poultry Science 1998;77:118-123.

Mohn S, Gillis AM, Moughan PJ, de Lange CF. Influence of dietary lysine and energy intakes on body protein deposition and lysine utilization in the growing pig. Journal of Animal Science 2000; 78:1510-9.

Moran Jr ET, Bilgili SF. Processing losses carcass quality and meat yield of poultry chickens as influenced by dietary lysine. Poultry Science 1990;69:702-709.

Morris TR, Al-Azzawi KR, Gous M, Simpson GL. Effects of protein concentration on responses to dietary lysine by chicks. British Poultry Science 1987;28:185-195.

Morris TR, Abbeb S. Effect on arginine and protein on chicks response to dietary lysine. British Poultry Science 1990;31:261-266.

Morris TR, Alazzawi K, Gous RM, Simpson GL. Effect of protein concentration on response to dietary lysine by chicks. British Poultry Science 1987;28:185-195.

Morris TR, Gous RM, Abbeb S, Effect of dietary protein concentration on the response of growing chicks to Methionine. British Poultry Science 1992;33:795-803

Munks B, Robinson A, Beach EF, Williams HH. Amino acids in the production of chicken egg and muscle. Poultry Science 1945;24:459-464.

National Resourch Council. Nutrient Requirements of Poultry. $9^{\text {th }}$ rev. ed. Washington: National Academy Press; 1994. 
Pesti GM, Leclercq BA, Chagneau M, Cochard T. Comparative responses of genetically lean and fat chickens to lysine arginine and non-essential amino acid supply. II. Plasma amino acid responses. British Poultry Science 1994;35:697-707.

Ravindran V, Hew LI, Ravindran G, Bryden WL. Apparent ileal digestibility of amino acids in dietary ingredients for broiler chickens. Animal Science 2005;81:85-97.

Rosebrough RW, Steele NC. Energy and protein relationships in the broiler. 1. Effect of protein levels and feeding regimens on growth body composition and in vitro lipogenesis of broiler chicks. Poultry Science 1985;64:119-126.

Rostango HS, Pupa JMR, Pack M. Diet formulation for broiler based on total versus digestible amino acids. The Journal of Applied Poultry Reserch 1995;4(1):293-299.

Si J, Kersey JH, Fritts CA, Waldroup PW. An evaluation of the interaction of lysine and methionine in diets for growing broilers. International Journal of Poultry Science 2004;3:51-60.

Smith E R, Pesti GM. Influence of broiler strain cross and dietary protein on performance of broilers. Poultry Science 1998;77:276-281.

Smith ER, Pesti GM, Bakalli RI, Ware GO, Menten JFM. Further studies on the influence of genotype and dietary protein on the performance of broilers. Poultry Science 1998;77:1678-1687.

Sterling KG, Pesti GM, Bakalli RI. The response of broiler chicks to dietary lysine and crude protein with different amino acid profiles [abstract]. Poultry Science 2002; 81 Suppl 1:26.

Sterling KG, Pesti GM, Bakalli RI. Performance of different broiler genotypes fed diets with varying levels of dietary crude protein and lysine. Poultry Science 2006;85:1045-1054

Summers JD, Slinger SJ, Ashton GC. The effect of dietary energy and protein on carcass composition with a note on a method for estimating carcass composition. Poultry Science 1965; 44:501-509.

Tesseraud S, Larbier M, Chagneau AM, Geraert PA. Effects of dietary lysine on muscle protein turnover in growing chickens. Reproduction Nutrition Development 1992; 32:163-175.

Tesseraud S, Peresson R, Chagneau AM. Dietary lysine deficiency greatly affects muscle and liver protein turnover in growing chickens. British Journal of Nutrition 1996;75:853-865.

Tessseraud S, Maaa N, Peresson R, Chagneau AM. Relative responses of protein turnover in three different skeletal muscles to dietary lysine deficiency in chicks. British Poultry Science 1996; 37:641-650.

Vazquez M, Pesti GM. Estimation of lysine requirement of broiler chicks for maximum body gain and feed efficiency. The Journal of Applied Poultry Research 1997;6:241-246.

Yaghobfar A, Boldaji F. Influence of level of feed input and procedure on metabolisable energy and endogenous energy loss (EEL) with adult cockerels. British Poultry Science 2002;43:696-704.

Yaghobfar A, zahedifar M. Endogenous losses of energy and amino acids in birds and their effect on true metabolisable energy values and availability of amino acids in maize. British Poultry Science 2003;44:719-725. 